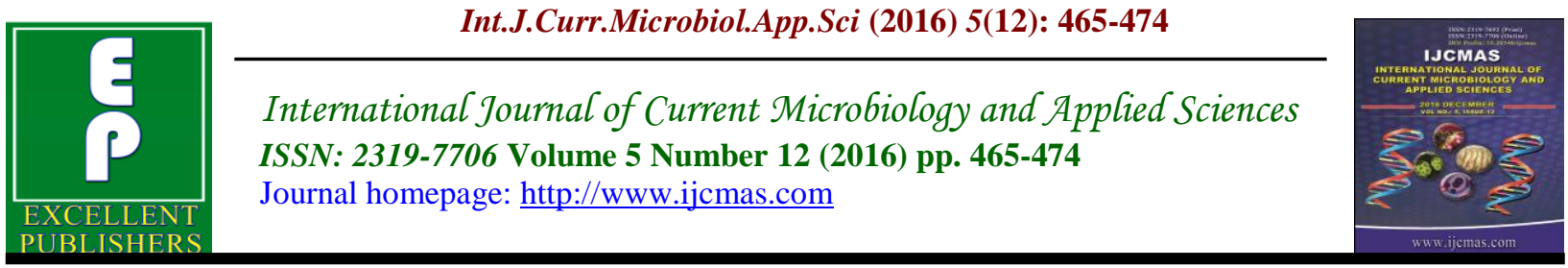

Original Research Article

http://dx.doi.org/10.20546/ijcmas.2016.512.050

\title{
Bioremediation of Diesel by Isolated Bacterial Species from River Chambal in Kota Region
}

\author{
Sanghmitra Thakur ${ }^{1}$, Ambika Kavia ${ }^{2}$, Sonika Saxena ${ }^{1}$, Sudipti Arora ${ }^{1}$, Anil K. Mathur ${ }^{2}$ \\ ${ }^{1}$ Dr. B. Lal Institute of Biotechnology, Jaipur (Raj.), India \\ ${ }^{2}$ Department of Civil Engineering, Rajasthan Technical University, Kota (Raj.), India \\ *Corresponding author:
}

Keywords

Biodegradation;

Bioremediation;

Diesel.

\section{Article Info}

Accepted:

18 November 2016

Available Online:

10 December 2016

\section{A B S T R A C T}

This study aims to observe the potential of indigenous bacteria from river Chambal flowing through Kota (Rajasthan) to degrade oil under in vitro conditions. Three strains namely Pseudomonas sp., Bacillus sp. and Staphylococcus sp. were isolated from Chambal waters through differential media screening which were then subjected to various biochemical tests for identification. Diesel was used as oil source in experiments. These strains were inoculated in sample water at different concentrations along with positive and negative controls for optimization of results. Method of gravimetric analysis was used for calculating degradation of oil. The inoculated samples were monitored for 30 days and high degradation of diesel was observed. Results revealed that these strains from river Chambal had better biodegradation potential for oil and can be used as potent hydrocarbon degraders.

\section{Introduction}

Oil spills are one of the major pollution causing reasons. This problem is very much concerned about sea and fresh water bodies like rivers, lakes etc. Oil spill pollution can be caused by various ways both of natural (e.g., climatic factors, natural disturbances) and anthropogenic origin (Murugesan et al., 2005; Ghilanlicael et al., 2003).

For the last three and a half decades, although the average number of incidents involving large oil spills has reduced, the total recorded amount of oil lost to the environment in 2015 was approximately 7000 tonnes. In the six year period 20102015, there have been 42 spills of 7 tonnes and over resulting in 33,000 tonnes of oil lost. $86 \%$ of this amount was split in just 10 incidents. Various factors account for this spillage. In the period $1970-2015,50 \%$ of large oil spills occurred while the vessels were underway in open water whereas the allisions, collisions and groundings accounted for $59 \%$ of the causes (Pandey et al., 2013; Mittal et al., 2009).

A river's health depends on the quality and quantity of its water which to some extent is destroyed by the oil spills. Chambal River is a tributary of the Yamuna River and is located in the Northern India flowing through three Indian states-Madhya Pradesh, 
Rajasthan and Uttar Pradesh. It is very important from economic point of view as it houses four dams. Water is used for irrigational, drinking, domestic and industrial purpose by the localities. But in the recent years, Garbage and Polluted water of entire Kota city is being dumped in the Chambal River in the absence of a proper sewage system. An Oil spill case was reported in Chambal River recently due to accidental oil spillage through Kota thermal power plant which is situated on the banks of river Chambal near Kota Barrage dam. Although various mechanical means were undertaken to clean the river, still traces of the oil spill were observed during the course of this study.

Hence bioremediation is a crucial process involving the use of microorganisms which would aid in cleaning the river and not cause any problem to the environment. In accordance to this, the present study was carried out to isolate potent hydrocarbon degraders from the site which would enhance the process of bioremediation if properly optimized.

Although various studies have been done on the water quality assessment and physicochemical parameters of river Chambal, yet no significant study has been done regarding oil spillage in the Chambal River. This study aims to illustrate the ability of the isolates to degrade the hydrocarbon and serve as a promising solution to this oil spillage problem.

\section{Materials and Methods}

\section{Experimental site}

Water sample was collected from river Chambal at Kota city, Rajasthan from Bhitariya kund site via grab sampling. The sample was contaminated by oil spillage occurred from the nearby thermal power plant due to leakage of fuel oil. The sample was then refrigerated for further analysis.

\section{Data collection and analysis}

The water sample collected was subjected to physicochemical analysis which included various parameters like Temperature, $\mathrm{pH}$, Dissolved oxygen (DO), Biochemical oxygen demand (BOD), Chemical oxygen demand (COD) and Oil and grease content.

\section{Isolation of bacteria}

Serial dilution of the sample was carried out for obtaining discrete colonies and then was inoculated on tributyrin nutrient agar medium by streaking. Three isolates were screened out from tributyrin plates which had shown Lipolytic activity. These isolates were further cultured on nutrient agar plates along with $0.5 \% \mathrm{v} / \mathrm{v}$ diesel. The obtained pure culture plates were kept in refrigeration at $4^{\circ} \mathrm{C}$. Broth cultures of these screened isolates were prepared in nutrient broth and kept on incubation at $30^{\circ} \mathrm{C}$ for 24 hours. Optical density of broth cultures were checked in every 24 hours until the isolates reached in growth phase. These broth cultures were then refrigerated at $4^{\circ} \mathrm{C}$ and used as inoculums for main experimental setup (Saksena et al., 2008).

\section{Identification and Biochemical Characterisation}

Gram staining of the three screened isolates was performed. Other biochemical tests which were carried out according to the Bergey's manual in accordance with gram staining were Lactose fermentation test, glucose test, sucrose test, mannitol test, catalase test, indole test, urease test, gelatin hydrolysis test, citrate utilization test, methyl red and voges proskauer test and nitrate reduction test (http://www.laleva.cc/environment/water.ht ml; Cappuccino et al., 2004). 


\section{Bioremediation studies}

The bacterial isolates were marked as strain I or KHC 1, strain II or KHC 2, and strain III or KHC 3. Nineteen $500 \mathrm{ml}$ flasks were taken and each flask was filled with sample water. 9 sample flasks were autoclaved and allowed to cool and were marked as positive control. 9 were left unautoclaved. All these 18 sample flasks were inoculated with respective broth culture along with diesel as substrate according to following table.1. The one left out sample flask was not inoculated with any broth culture and was marked as negative control. These sample flasks were kept in incubation at $30^{\circ} \mathrm{C}$ and were used for gravimetric analysis in regular time intervals for checking the oil degradation (Ramesh $e t$ al., 2014; Priya et al., 2009).

Gravimetric analysis- For checking oil degradation, $25 \mathrm{ml}$ of cultured sample was taken out from each sample flask and added with $5 \mathrm{ml}$ petroleum ether and $1 \mathrm{ml} \mathrm{H}_{2} \mathrm{SO}_{4}$ and kept for 30 minutes in separating funnel. Two layers were formed- one organic and one aqueous. The aqueous layer which was formed at bottom was drained out and organic layer was filtered out in pre-weighed beaker. These beakers were kept in waterbath till they evaporated to dryness. The gravimetric estimation of residual oil content was made by weighing the beakers and subtracting the weight from previous ones.

\section{Results and Discussion}

\section{Physicochemical analysis}

The results for various physicochemical parameters are listed in the table-2.

The values obtained were not in the range of the permissible limits (CPCB) which indicated that the river water was polluted.

\section{Isolation of bacteria}

The bacterial isolates were identified during primary screening carried out on tributyrin nutrient agar plates as they had shown Lipolytic activity.

\section{Identification of bacteria}

The gram staining results of the three isolates were as follows:

Strain I- Gram negative rod shaped

Strain II- Gram positive rod shaped

Strain III- Gram positive cocci

Biochemical tests were conducted for further identification of strains in accordance with the Bergey's manual (Table.3).

Strain I: Lactose fermentation test was negative and glucose test was also negative which indicated that it was expected to be Pseudomonas spp.

Strain II: Endospore staining was positive and mannitol test was negative which indicated that it was expected to be Bacillus spp

Strain III: Catalase test was positive and mannitol test was also positive which indicated that it was expected to be Staphylococcus spp.

\section{Bioremediation studies}

The gravimetric analysis results obtained are shown in the following table: 4

The data shows that isolated microorganisms belonged to Pseudomonas sp., Bacillus sp. and Staphylococcus sp. In 
this study we found that $95 \%$ biodegradation of oil was found in Pseudomonas sp. with $0.1 \%$ of inoculum, $95 \%$ biodegradation of oil was found in Bacillus sp. with $0.5 \%$ of inoculum and $95 \%$ biodegradation of oil was found in Staphylococcus sp. with $0.1 \%$ of inoculum after 30 days of incubation.

The correct identification of these expected strains can be done by DNA sequencing.
The present study was carried out to assess the quality of contaminated water. These qualities determine the capability of bacterial isolates to biodegrade petroleum compounds and their wastes like oily sludge, a hazardous hydrocarbon waste generated by the petroleum industry.

Table.1 Experimental setup

\begin{tabular}{llll} 
S. N. & Strain/ Sample & Inoculum conc. (\%) & Diesel conc.(\%) \\
\hline 1 & I/ autoclaved & 0.1 & 0.1 \\
2 & I/ autoclaved & 0.5 & 0.1 \\
3 & I/autoclaved & 1 & 0.1 \\
4 & I/ un autoclaved & 0.1 & 0.1 \\
5 & I/ un autoclaved & 0.5 & 0.1 \\
6 & I/ un autoclaved & 1 & 0.1 \\
7 & II/ autoclaved & 0.1 & 0.1 \\
8 & II/ autoclaved & 0.5 & 0.1 \\
9 & II/ autoclaved & 1 & 0.1 \\
10 & II/ un autoclaved & 0.1 & 0.1 \\
11 & II/ un autoclaved & 0.5 & 0.1 \\
12 & II/ un autoclaved & 1 & 0.1 \\
13 & III/ autoclaved & 0.1 & 0.1 \\
14 & III/ autoclaved & 0.5 & 0.1 \\
15 & III/ autoclaved & 1 & 0.1 \\
16 & III/ un autoclaved & 0.1 & 0.1 \\
17 & III/ un autoclaved & 0.5 & 0.1 \\
18 & III/ un autoclaved & 1 & 0.1 \\
\hline 19 & Negative & & 0.1
\end{tabular}

Table.2 Physicochemical analysis results

$\begin{array}{ll}\text { Parameter } & \text { Value } \\ \mathrm{pH} & 5.8 \\ \text { Temperature } & 30^{\circ} \mathrm{C} \\ \text { Dissolved oxygen } & 6.5 \mathrm{ppm} \\ \text { Biochemical oxygen demand } & 1.72 \mathrm{ppm} \\ \text { Chemical oxygen demand } & 17 \mathrm{ppm} \\ \text { Oil and grease content } & 200 \mathrm{ppm}\end{array}$


Table.3 Other Biochemical test

\begin{tabular}{llll} 
TEST & KHC 1 & KHC 2 & KHC 3 \\
Gram staining & $-\mathrm{ve}$ (rod) & +ve (bacilli) & $+\mathrm{ve}$ (cocci) \\
Lactose test & $+\mathrm{ve}$ & $-\mathrm{ve}$ & $+\mathrm{ve}$ \\
Glucose test & $-\mathrm{ve}$ & $-\mathrm{ve}$ & $-\mathrm{ve}$ \\
Sucrose test & $+\mathrm{ve}$ & $+\mathrm{ve}$ & $+\mathrm{ve}$ \\
Nitrate reduction & $-\mathrm{ve}$ & $-\mathrm{ve}$ & $-\mathrm{ve}$ \\
test & & & \\
Urease test & $-\mathrm{ve}$ & $-\mathrm{ve}$ & $-\mathrm{ve}$ \\
Gelatin hydrolysis & $+\mathrm{ve}$ (rapid) & $+\mathrm{ve}$ (rapid) & $+\mathrm{ve}$ (slow) \\
Test & & & \\
TSIA test & $-\mathrm{ve}$ & $-\mathrm{ve}$ & $-\mathrm{ve}$ \\
Indole test & $-\mathrm{ve}$ & $-\mathrm{ve}$ & $-\mathrm{ve}$ \\
MR test & $+\mathrm{ve}$ & $-\mathrm{ve}$ & $-\mathrm{ve}$ \\
VP test & $-\mathrm{ve}$ & $-\mathrm{ve}$ & $-\mathrm{ve}$ \\
Citrate utilisation & $+\mathrm{ve}$ & $-\mathrm{ve}$ & $-\mathrm{ve}$ \\
test & & & Btaphylococcus $s p$. \\
\hline Identified isolates & Pseudomonas $s p$. & $\underline{\text { Bacillus } s p .}$
\end{tabular}

Table.4 Gravimetric analysis results

\begin{tabular}{|c|c|c|c|c|c|c|c|c|}
\hline $\begin{array}{l}\text { S. } \\
\text { No }\end{array}$ & Strain/ Sample & $\begin{array}{l}\text { Inoculu } \\
\text { m conc. } \\
(\%)\end{array}$ & $\begin{array}{l}0^{\mathrm{MH}} \\
\text { Day } \\
\text { (in gms/ } \\
25 \mathrm{ml} \text { ) }\end{array}$ & $\begin{array}{l}5^{1 \mathrm{HI}} \\
\text { Day } \\
\text { (in gms/ } \\
25 \mathrm{ml} \text { ) }\end{array}$ & $\begin{array}{l}10^{\mathrm{HI}} \\
\text { Day } \\
\text { (in gms/ } \\
25 \mathrm{ml} \text { ) }\end{array}$ & $\begin{array}{l}15^{111} \\
\text { Day } \\
\text { (in gms/ } \\
25 \mathrm{ml} \text { ) }\end{array}$ & $\begin{array}{l}30^{111 /} \\
\text { Day } \\
\text { (in gms/ } \\
25 \mathrm{ml} \text { ) }\end{array}$ & $\begin{array}{l}\% \\
\text { Degradation } \\
\text { on } 30^{\text {th }} \text { day } \\
\text { w.r.t } 0^{\text {th }}\end{array}$ \\
\hline 1 & I/ autoclaved & 0.1 & 0.12 & 0.08 & 0.04 & 0.02 & 0.02 & 83.33 \\
\hline 2 & I/ autoclaved & 0.5 & 0.12 & 0.08 & 0.04 & 0.01 & 0.01 & 91.66 \\
\hline $\begin{array}{l}3 \\
4\end{array}$ & $\begin{array}{l}\text { I/autoclaved } \\
\text { I/ un autoclaved }\end{array}$ & $\begin{array}{c}1 \\
0.1\end{array}$ & $\begin{array}{l}0.12 \\
0.20\end{array}$ & $\begin{array}{l}0.07 \\
0.11\end{array}$ & $\begin{array}{l}0.05 \\
0.07\end{array}$ & $\begin{array}{l}0.03 \\
0.01\end{array}$ & $\begin{array}{l}0.02 \\
0.01\end{array}$ & $\begin{array}{l}83.33 \\
95\end{array}$ \\
\hline 5 & I/ un autoclaved & 0.5 & 0.20 & 0.11 & 0.06 & 0.03 & 0.02 & 90 \\
\hline 6 & I/ un autoclaved & 1 & 0.20 & 0.13 & 0.08 & 0.04 & 0.02 & 90 \\
\hline 7 & II/ autoclaved & 0.1 & 0.12 & 0.07 & 0.05 & 0.04 & 0.03 & 75 \\
\hline 8 & II/ autoclaved & 0.5 & 0.12 & 0.07 & 0.04 & 0.02 & 0.02 & 83.33 \\
\hline 9 & II/ autoclaved & 1 & 0.12 & 0.08 & 0.06 & 0.04 & 0.02 & 83.33 \\
\hline 10 & II/ un- autoclaved & 0.1 & 0.20 & 0.14 & 0.07 & 0.03 & 0.02 & 90 \\
\hline 11 & II/ un autoclaved & 0.5 & 0.20 & 0.11 & 0.07 & 0.01 & 0.01 & 95 \\
\hline 12 & II/ un autoclaved & 1 & 0.20 & 0.13 & 0.08 & 0.04 & 0.02 & 90 \\
\hline 13 & III/ autoclaved & 0.1 & 0.12 & 0.09 & 0.05 & 0.02 & 0.02 & 83.33 \\
\hline 14 & III/ autoclaved & 0.5 & 0.12 & 0.07 & 0.04 & 0.01 & 0.01 & 91.66 \\
\hline 15 & III/ autoclaved & 1 & 0.12 & 0.09 & 0.05 & 0.06 & 0.04 & 66.66 \\
\hline 16 & III/ un autoclaved & 0.1 & 0.20 & 0.12 & 0.08 & 0.01 & 0.01 & 95 \\
\hline 17 & III/ un autoclaved & 0.5 & 0.20 & 0.12 & 0.07 & 0.02 & 0.02 & 90 \\
\hline 18 & III/ un autoclaved & 1 & 0.20 & 0.13 & 0.08 & 0.03 & 0.02 & 90 \\
\hline 19 & Negative & & 0.20 & 0.15 & 0.12 & 0.05 & 0.05 & 75 \\
\hline
\end{tabular}


Fig.1 Sampling site

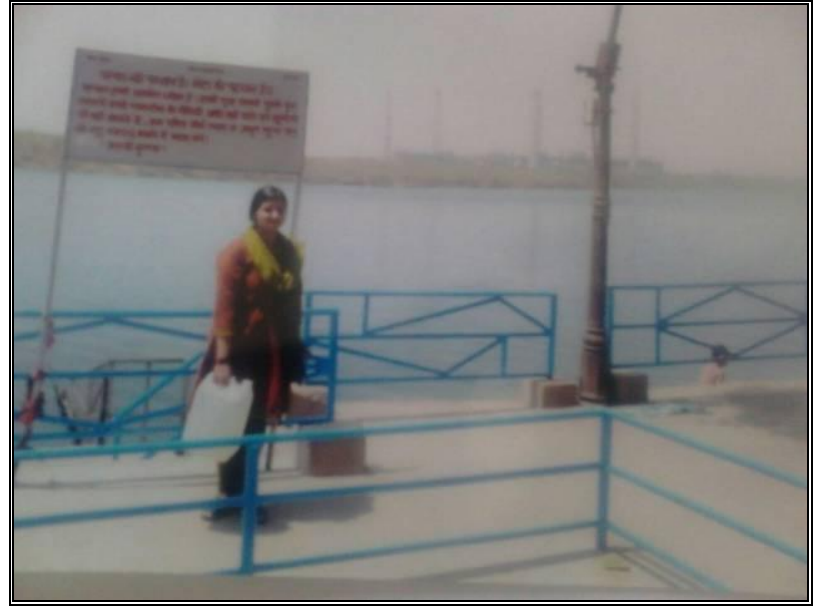

Fig.2 Lipolytic activity

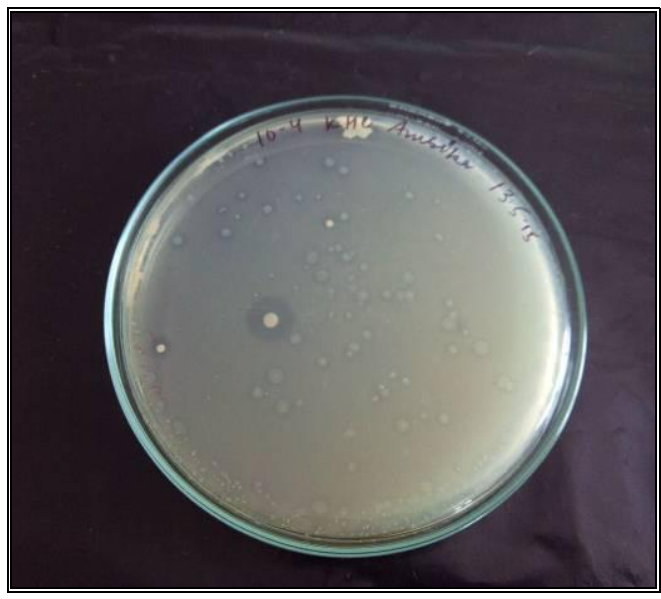

Fig.3 Lactose fermentation test

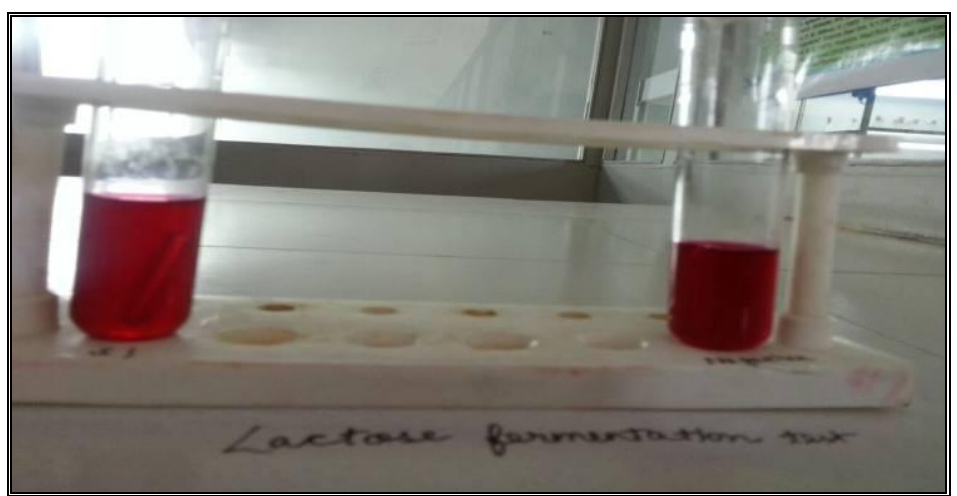


Fig.4 Glucose test

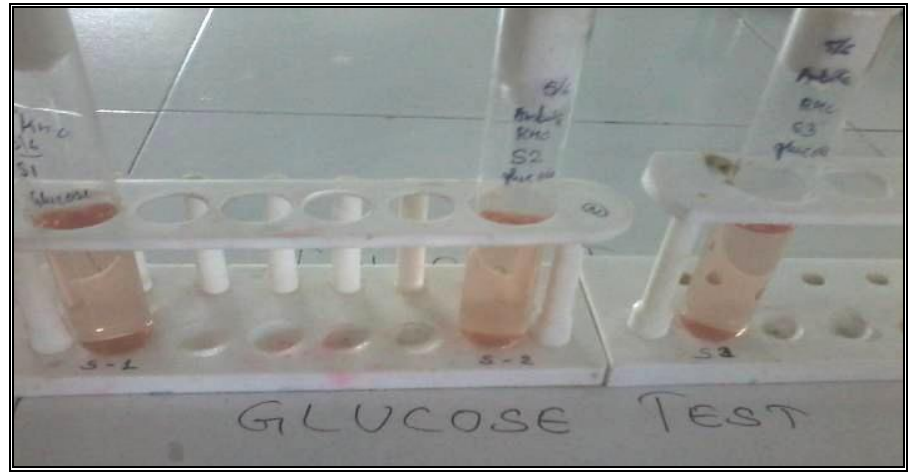

Fig.5 Mannitol test

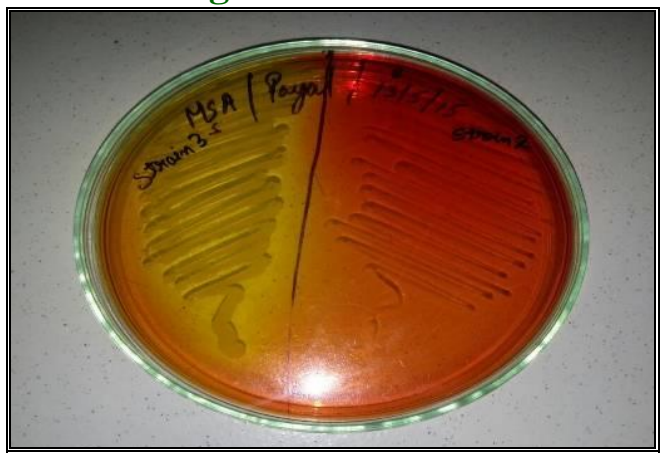

Fig.6 Catalase test

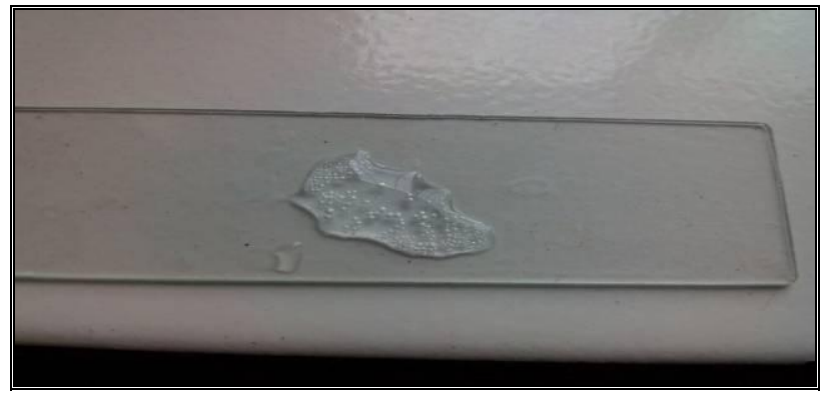

Fig.7 Mannitol test

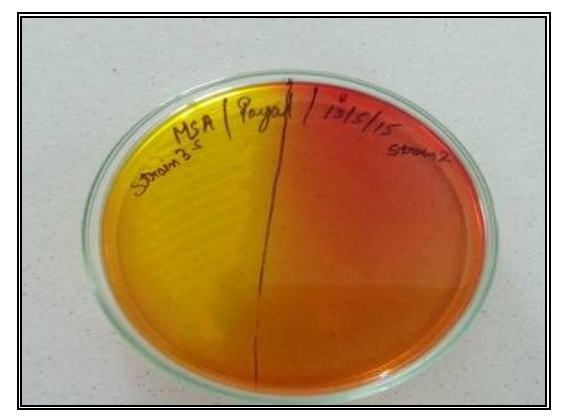


Fig.8 Biochemical test
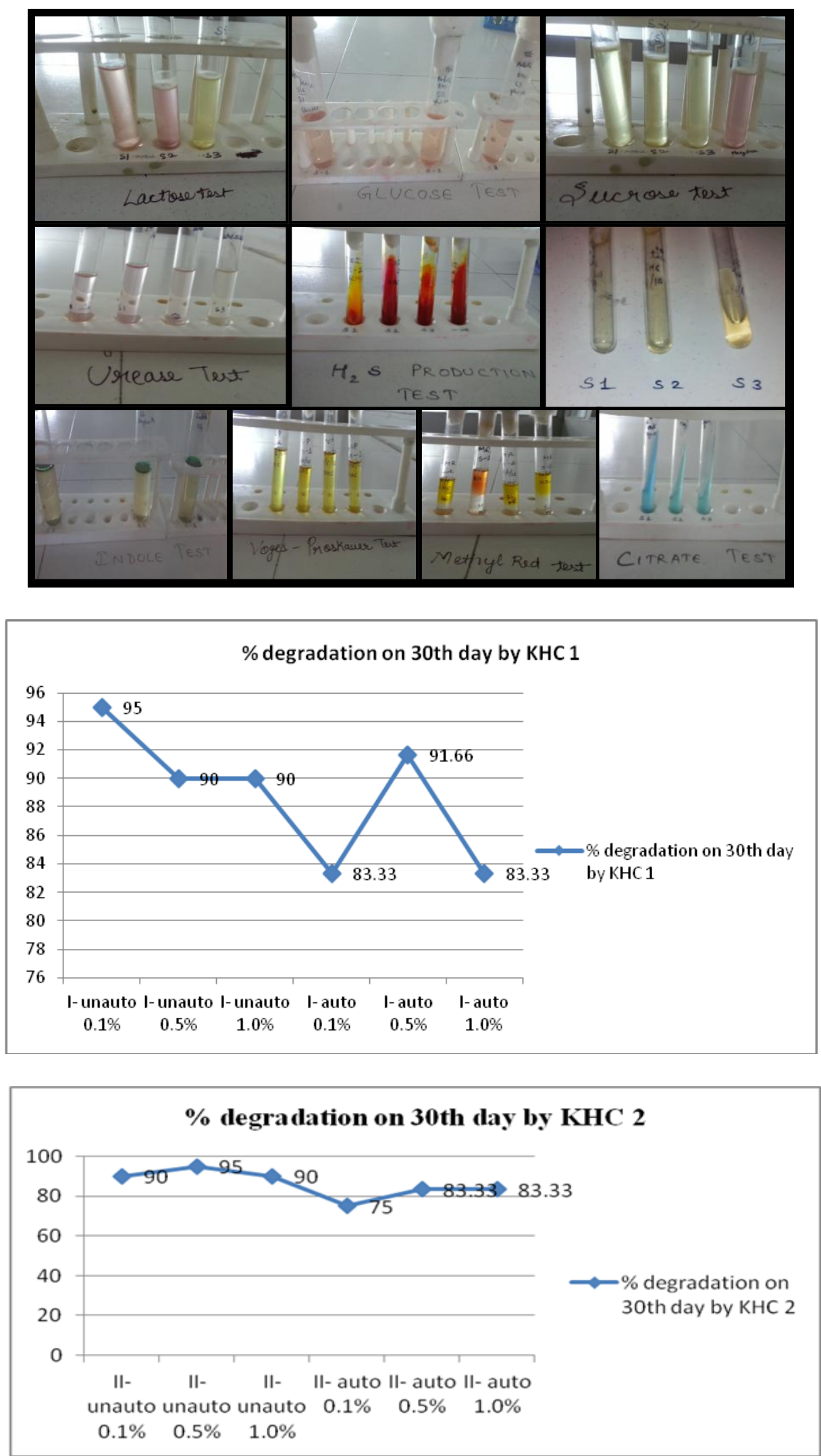

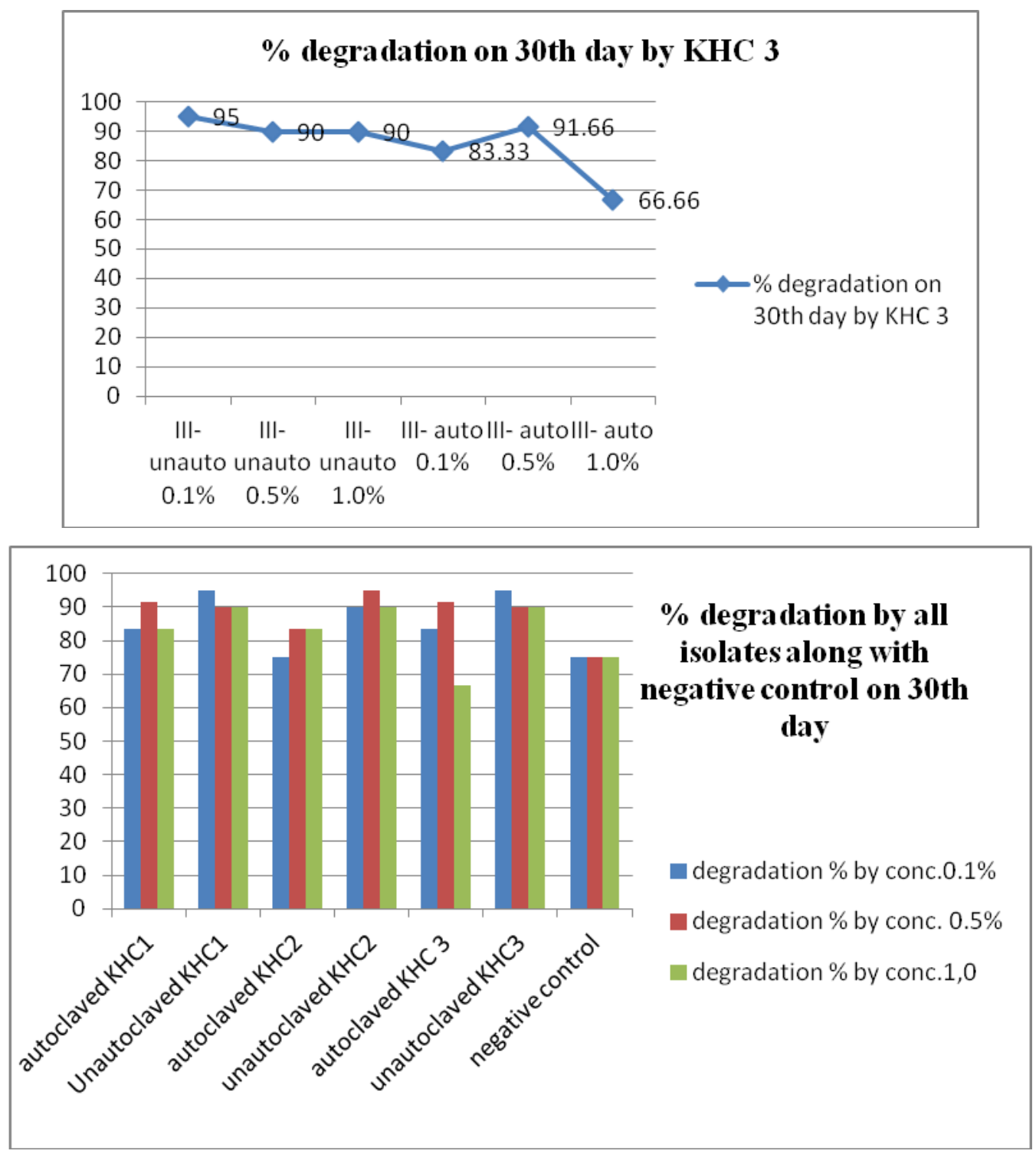

Certain bacteria degrade hydrocarbons by default. The ability of various indigenous bacteria, especially those isolated from contaminated sites, to metabolize crude oil or aliphatic hydrocarbons are well known. In this study, bacteria that are able to grow on heavy oil as a carbon and energy source were isolated from aquatic sites of river Chambal flowing through Kota, Rajasthan.

The selective enrichment technique was used for selecting hydrocarbon degraders. Growth of the isolated bacteria on medium Tributyrin agar demonstrated the presence of hydrocarbon and oil-degrading activities in isolated bacterial strains. The unautoclaved bacteria samples had shown more degradation which suggests that the microorganisms are degrading better when provided with natural conditions and natural microflora around.

In conclusion, in this study we found that 95\% biodegradation of oil was found in Pseudomonas sp. with $0.1 \%$ of inoculum, $95 \%$ biodegradation of oil was found in Bacillus sp. with $0.5 \%$ of inoculum and $95 \%$ biodegradation of oil was found in 
Staphylococcus sp. with $0.1 \%$ of inoculum after 30 days of incubation. Gravimetric analysis method was used to determine the amount of oil degraded. The unautoclaved samples had shown good degradation than autoclaved ones which means these bacteria works better in natural environments with natural flora present in their home river.

It is suggested from the present investigations that diversity of indigenous microbes could be exploited using high throughput screening methods and the possible role of enzymes involved must be studied. These species of bacteria can be further utilized for treating municipal wastes containing oils and can be used for treating oil spills.

\section{References}

Cappuccino James, G., and Sherman Natali. 2004. "Microbiology - A Laboratory Manual”, ISBN-13: 978-0805328363, Benjamin Cummings; 7 edition.

Ghilanlicael, Amanuel Menghs. 2003. "Isolation and characterization of nalkane utilizing bacteria, which produce bioemulsifiers", Dissertation, University of Cape Town, South Africa.

http://rajasthanpatrika.patrika.com/story/raja sthan/oil-leak-in-chambal-fromthermal-968103.html http://www.laleva.cc/environment/water.htm 1

Mittal, Anupama and Singh, Padma. 2009. "Isolation of hydrocarbon degrading bacteria from soils contaminated with crude oil spills", Indian $J$. Experimental Biol., Vol.47, pp. 760765.

Murugesan, A.G. and Rajakumari, C. 2005. "Environmental Science and Biotechnology: Theory and Techniques", MJP Publishers; 1st edition.

Pandey, Amit and Chandra, Rashmi. 2013. "Isolation of oil degrading bacteria from oil contaminated soil and expression of oil degrading genes in non oil degrading bacteria", J. Drug Discovery and Therapeutics, 1(11): 01-17.

Priya, T., and Usharani, G. 2009. "Comparative study for biosurfactant production by using Bacillus subtilis and Pseudomonas aeruginosa", Bot. Res. Int., Vol. 2(4).

Ramesh, M., Ashwini and Somashekar, Pratibha. 2014. "Bioremediation of Oil Spill an Invasion by Bacteria to a Safe Environment", Indian J. Appl. Res., Vol.4.

Saksena D.N., Garg, R.K. and Rao, R.J. 2008. "Water quality and pollution status of Chambal river in National Chambal sanctuary, Madhya Pradesh", J. Environ. Biol., 29(5): 701-710.

\section{How to cite this article:}

Sanghmitra Thakur, Ambika Kavia, Sonika Saxena, Sudipti Arora, Anil K. Mathur. 2016. Bioremediation of Diesel by Isolated Bacterial Species from River Chambal in Kota Region. Int.J.Curr.Microbiol.App.Sci. 5(12): 465-474. doi: http://dx.doi.org/10.20546/ijcmas.2016.512.050 